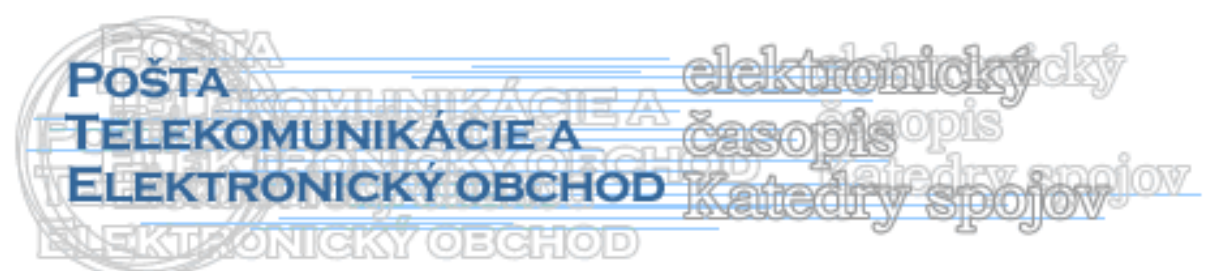

\title{
STANOVENÍ NÁKLADŮ ZÁVAZKU UNIVERZÁLNÍ POŠTOVNÍ SLUŽBY
}

\author{
Libor Švadlenka, Jan Roth ${ }^{1}$
}

\section{Úvod}

Termín plného otevření poštovního trhu České republiky konkurenci je naplánován na 1. ledna 2013. Je zřejmé, že otevření trhu konkurenci je krok správným směrem, nicméně podmínky poskytování poštovních služeb $\mathrm{v}$ takto otevřeném poštovním trhu musí být nastaveny tak, aby nedošlo k ohrožení poskytování univerzální poštovní služby, která je v současné době provozována Českou poštou, s. p. a je financována prostřednictvím poštovní výhrady. V diskusích na toto téma je neustále zmiňováno riziko, že po ztrátě vyhrazené oblasti by se mohla stát univerzální služba pro jejího poskytovatele nepřiměřeným finančním břemenem. Při těchto úvahách je tak kličcové především správné a přesné stanovení skutečných nákladů závazku univerzální poštovní služby.

\section{Univerzální poštovní služba}

Povinnost poskytovat univerzální poštovní službu plyne členským státům EU ze směrnice 97/67/ES. Konkrétně je zde stanoveno, že členské státy mají povinnost zajistit pro své uživatele poštovních služeb univerzální službu zahrnující trvalé poskytování poštovní služby ve stanovené kvalitě ve všech místech na jejich území za dostupné ceny pro všechny uživatele. $\mathrm{Z}$ dalších bodů článku 3 této směrnice vyplývá pro poskytovatele univerzální poštovní služby povinnost zajistit tuto univerzální poštovní službu během všech pracovních dní a nejméně pětkrát týdně, kromě okolností nebo geografických podmínek považovaných národním regulačním orgánem za mimořádné, a to minimálně jedním sběrem a jedním dodáním. Univerzální poštovní služba přitom musí obsahovat minimálně tyto služby:

- $\quad$ sběr, tř́idění, přepravu a dodání poštovních zásilek do $2 \mathrm{~kg}$,

- $\quad$ sběr, trrídění, přepravu a dodání poštovních balíků do $10 \mathrm{~kg}$ (národní regulační autority mohou v jednotlivých členských státech zvýšit limit hmotnosti až na 20 kg),

- $\quad$ služby doporučených zásilek a zásilek s udanou cenou.

Další povinnosti týkající se poskytování univerzální poštovní služby v rámci EU vyplývají například z bodu 5 této směrnice, stanovující následující požadavky:

- $\quad$ nabízená služba musí zaručovat, že budou splněny základní potřeby,

- uživatelům musí být nabízena stejná služby za srovnatelných podmínek,

- $\quad$ služba se stane dostupnou bez jakékoli diskriminace ve kterékoli podobě, zvláště bez diskriminace vzniklé z politických, náboženských nebo ideologických důvodů,

\footnotetext{
${ }^{1}$ Ing. Libor Švadlenka, Ph.D., Univerzita Pardubice, Dopravní fakulta Jana Pernera, Katedra dopravního managementu, marketingu a logistiky, Studentská 95, 53210 Pardubice, Tel.: 466036375, E-mail: Libor.Svadlenka@upce.cz

${ }^{1}$ Ing. Jan Roth, Česká pošta, s.p., Sekce řízení poštovní přepravy, Politických Vězňu 909/4, 11500 Praha 1, Tel.: 221132 467, E-mail: Roth.Jan@cpost.cz.
} 
- $\quad$ služba nebude přerušena nebo zastavena s výjimkou případů vy̌šśí moci,

- $\quad$ služba se bude rozvíjet $\mathrm{v}$ závislosti na technickém, hospodářském a společenském prostředí a na potřebách uživatelů.

Pokud jde o podmínky v ČR, je třeba uvést, že předmětný český právní předpis, tj. zákon č. 29/2000 Sb., ve znění pozdějších předpisů nehovoří o univerzální poštovní službě, ale o tzv. základní poštovní službě, což je podle $\S 2$ písm. j) tohoto zákona poštovní služba a zahraniční poštovní služba, která je vzhledem k potřebám veřejnosti pod ochranou státu zajišt'ovaná způsobem podle tohoto zákona. § 19 tohoto zákona stanoví povinnost zajistit všeobecnou dostupnost těchto služeb na celém území ČR, $\mathrm{s}$ tím, že národní regulační autorita (NRA), kterou je v ČR Český telekomunikační úřad (ČTÚ) stanovila v poštovním věstníku, které služby jsou vzhledem k potřebám veřejnosti službami základními, a to uvedením obecných charakteristik těchto základních služeb. Pojmy základní poštovní služba a univerzální poštovní služba vyjadřují tedy stejnou věc, nicméně obsahově se přeci jen trochu liší. Základní služba v sobě obsahuje i poštovní poukazy, což univerzální poštovní služba vůbec nezahrnuje.

\section{Finanční náročnost poskytování univerzální poštovní služby}

I v plně liberalizovaném prostředí je povinnost ČR jako členské země EU zajistit, aby byla UPS poskytována. Je to ale možné za podmínek, kdy nebude moci národní poštovní operátor (dále jen NPO), jako pravděpodobný počáteční poskytovatel univerzální poštovní služby v plně liberalizovaném trhu, kompenzovat náklady na poskytování UPS pomocí př́imů z vyhrazených služeb? Nepředstavuje závazek UPS nespravedlivé finanční břemeno pro jejího poskytovatele? Jak by měla být UPS financována? Kolik vlastně stojí UPS? Na všechny položené otázky lze najít odpověd' určením skutečných nákladů závazku UPS. A právě to je úkol, před kterým stojí i český poštovní sektor. Je však zřejmé, že se nebude jednat o lehký úkol, nebot' při tomto výpočtu je mimo jiné třeba uvažovat podmínky již liberalizovaného trhu, dále je třeba odhadnout, co by poskytovatel UPS nedělal, kdyby nebyl vázán povinností realizovat závazek UPS a samozřejmě také je třeba odhadnout jaký rozsah vlastně bude mít UPS v plně liberalizovaném trhu.

Významnou roli při výpočtu skutečných nákladů závazku UPS sehraje NRA (Český telekomunikační úřad), která by měla tento výpočet principielně ověřovat. Samozřejmě pokud vyjdou skutečné náklady závazku UPS kladné a budou pro poskytovatele UPS představovat nepřiměřenou finanční zátěž, je třeba přistoupit $\mathrm{k}$ dodatečnému financování těchto dodatečných nákladů.

\section{Kalkulace nákladů}

Postup výpočtu čistých nákladů závazku UPS je stanoven v př́loze I Směrnice 2008/6/EC. V části B této př́llohy je naznačeno, jak lze náklady počítat [4]:

„Čisté náklady na univerzální službu se vypočítaji jako rozdíl mezi čistými náklady určeného poskytovatele UPS, který vykonává povinnosti univerzální služby, a téhož poskytovatele poštovních služeb, který povinnosti univerzální služby nevykonává.“ 
Z toho vyplývá, že čisté náklady na zajištění UPS je možno vypočítat z tohoto vztahu:

$$
\check{C} N_{U P S}=\check{C} N^{s U P S}-\check{C} N^{b e z U P S}
$$

kde:

$$
\begin{array}{ll}
\check{C} N_{U P S} & \text { čisté náklady na UPS } \\
\check{C} N^{\text {sUPS }} & \text { čisté náklady operátora v případě poskytování UPS } \\
\check{C} N^{\text {bezUPS }} & \text { čisté náklady operátora v připadě neposkytování UPS }
\end{array}
$$

V případě kladného výsledku by bylo prokázáno, že závazek UPS je zdrojem skutečných nákladů a představuje-li pro jejího poskytovatele nepřiměřené finanční břemeno, měl by se kompenzovat. Při záporném výsledku by UPS generovala zisk, tudíž by zde byla otázka kompenzace UPS neopodstatněná.

Ve výpočtu je přitom třeba zohlednit i všechny možné tržní výhody, které mohou NPO z poskytování UPS vzniknout, včetně nároku na přiměřený zisk a pobídek $\mathrm{k}$ nákladové efektivnosti.

\section{Referenční scénář}

Než začne poskytovatel UPS se samotným výpočtem čistých nákladů, měl by vypracovat tzv. referenční scénář, na základě kterého stanoví služby, které by v př́padě neexistujícího závazku UPS dobrovolně nerealizoval. Referenční scénář by měla následně posoudit NRA. Ve směrnici 2008/6/EC je tato skutečnost stanovena takto [4]: „NRA je odpovédný za ověreni čistých nákladů. Poskytovatel či poskytovatelé univerzální služby spolupracují s NRA, aby mu umožnili čisté náklady ověrit. "

V referenčním scénáŕi by měl poskytovatel UPS specifikovat, jak by se choval v prrípadě, kdyby povinnost poskytovat UPS neměl. Ve scénáři by měly být zahrnuty hlavně specifika lokálního trhu, produkty, služby, cenotvorba, četnost dodávání, poštovní sít', hospodářská soutěž na trhu, ale i ostatní aspekty, které mohou mít na stanovení čistých nákladů UPS vliv.

\section{Metody výpočtu čistých nákladů}

Pro výpočet nákladů spojených s realizací služeb lze obecně použít tzv. metodu úplně rozdělených nákladů $(\text { FDC })^{2}$, která je použivána NPO jako účetní metoda k přípravě oddělených regulačních účtů pro poštovní operace. Bohužel tuto metodu nelze využít pro výpočet čistých nákladů na poskytování UPS, protože nebere v úvahu tržní výhody, nárok na přiměřený zisk a pobídku pro nákladovou efektivitu.

Co se týká kalkulace čistých nákladů na zajištění UPS, je potřeba využít jiné metody. V současné době jsou nejdiskutovanější tyto:

- $\quad$ Metoda vyhnutelných nákladů (MVN),

- $\quad$ Metoda vstupního ocenění (MVO),

- $\quad$ Metoda rentability nákladů (MRN).

\footnotetext{
${ }^{2}$ Fully Distributed Costs
} 
Všechny tři metody mají své výhody i nevýhody, které je potřeba vzít v úvahu dříve, než se přistoupí k samotnému výpočtu čistých nákladů závazku UPS.

Princip jednotlivých metod lze zjednodušeně znázornit obrázkem č. 1, na kterém jsou zobrazeny vazby mezi čtyřmi alternativami, které mohou ve vztahu k poštovnímu operátorovi nastat, když:

1. poskytuje UPS v monopolním prostředí (čisté náklady $\check{C} N_{M U}$ ),

2. neposkytuje UPS v monopolním prostředí (čisté náklady $\check{C} N_{M N}$ ),

3. poskytuje UPS v liberalizovaném prostředí (čisté náklady $\check{C} N_{L U}$ ),

4. neposkytuje UPS v liberalizovaném prostředí (čisté náklady $\check{C} N_{L N}$ ).

obrázek č. 1 -Vztah metod výpočtu čistých nákladi̊ závazku UPS k jednotlivým alternativám

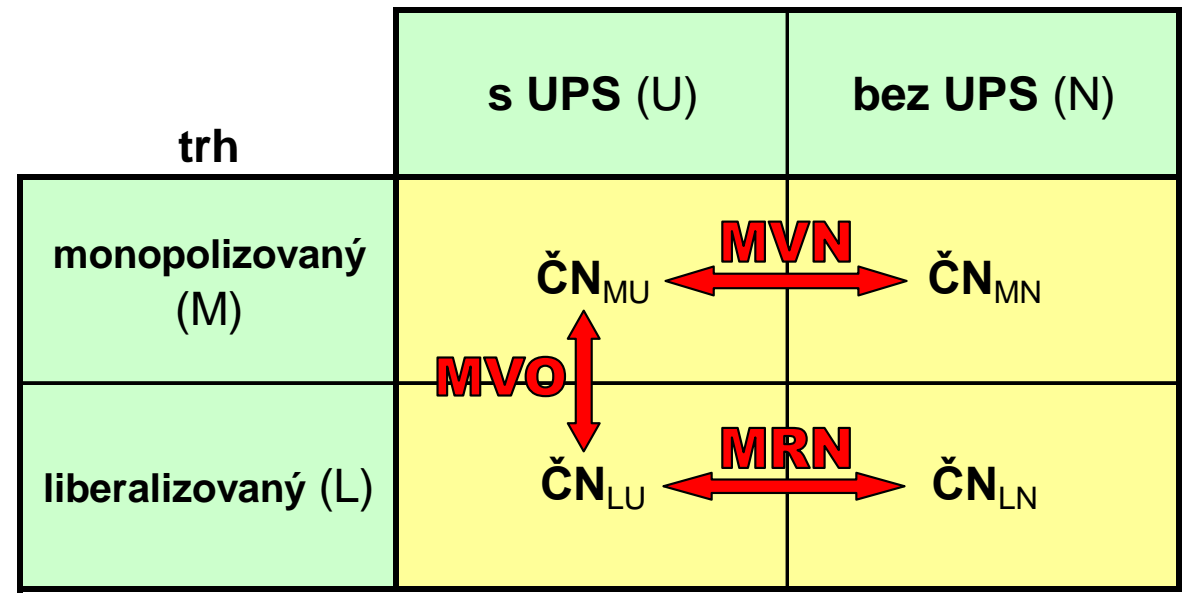

\section{Metoda vyhnutelných nákladů}

V současné době se jedná o nejrozšířenější metodu výpočtu čistých nákladů závazku UPS. Název této metody je odvozen z anglického Net Avoidable Costs (NAC). Vyhnutelné náklady se kalkulují jako rozdíl provozních čistých nákladů NPO se závazkem a bez něj.

Základní vztah kalkulace pomocí metody MVN vypadá takto:

$$
\check{C} N_{M V N}=\check{C} N_{M U}-\check{C} N_{M N}
$$

kde:

$$
\begin{aligned}
& \check{C} N_{M V N} \text { čisté náklady kalkulované metodou vyhnutelných nákladi̊ } \\
& \check{C} N_{M U} \quad \text { čisté náklady operátora v připadě poskytování UPS v monopolním } \\
& \text { prostředí } \\
& \check{C} N_{M N} \text { čisté náklady operátora v případě neposkytování UPS } \\
& v \text { monopolním prostředí }
\end{aligned}
$$

I k dyž je MVN v e své p o dtstě v souladu s evropskou směrnicí, přesto vykazuje několik nedostatků. 
Zásadním problémem této metody je skutečnost, že nerozlišuje mezi zákazníky a adresáty. Tato metoda se snaží spočítat ztráty plynoucí z obsluhy neziskových zákazníků, které by podnik maximalizující zisk (bez závazku univerzální služby) nikdy neobsluhoval. Ve skutečnosti ale tento cíl metoda nemůže splnit. Aby totiž bylo možné zjistit, zda se jedná o ztrátového zákazníka, je nutné začít u zákazníka-odesílatele, tj. toho, kdo ve skutečnosti platí poštovné. Metoda MVN je však založena na zákaznících-adresátech. Chybně předpokládá, že zákazníci nebudou reagovat v př́ípadě, že poskytovatel univerzální služby nebude nadále schopen plnit všechny jejich požadavky týkající se doručování.

Další nevýhodou metody MVN je to, že oceňování nákladů je založeno na stávající marketingové situaci, a nikoli na situaci liberalizovaného poštovního trhu.

Nakonec i výsledná hodnota nákladů univerzální služby je ovlivněna mírou agregace vstupních dat při tvorbě segmentů, tj. definicí velikosti jednotlivých segmentů. Čím podrobnější budou segmenty, tím větší budou náklady závazku univerzální služby.

\section{Metoda vstupního ocenění}

Další metodou použitelnou pro výpočet čistých nákladů je tzv. Metoda vstupního ocenění, jejíž název je převzat z anglického termínu Entry Pricing (EP). Bohužel MVO není plně v souladu s evropskou směrnicí, protože je jejím výsledkem součet nákladů na univerzální službu a zisk poskytovatele UPS, který by byl úplným otevřením poštovního trhu ztracen. Jsou tak vypočteny hlavně náklady na plnou liberalizaci, ale ne př́mo výhradně náklady na UPS.

Metoda MVO vychází z následujícího matematického vztahu:

$$
\check{C} N_{M V O}=\check{C} N_{L U}-\check{C} N_{M U}
$$

kde:

$$
\begin{array}{ll}
\check{C} N_{M V O} & \text { čisté náklady kalkulované metodou vstupního ocenění } \\
\check{C} N_{L U} & \begin{array}{l}
\text { čisté náklady operátora v př́padè poskytování UPS } \\
\text { v liberalizovaném prostředí }
\end{array} \\
\check{C} N_{M U} & \begin{array}{l}
\text { čisté náklady operátora v př́padě poskytování UPS v monopolním } \\
\text { prostredi }
\end{array}
\end{array}
$$

Co se týká dalších nevýhod MVO, jsou ve své podstatě podobné jako u předchozí metody. Hlavní slabiny MVO jsou hlavně voblasti definování neziskových tržních a zákaznických segmentů.

\section{Metoda rentability nákladů}

Z anglického termínu Profitability Cost byl odvozen název pro metodu rentability nákladů. Poprvé byla tato metoda představena a diskutována v roce 2000 [8], [9].

Vztah pro výpočet pomocí metody MRN je tento:

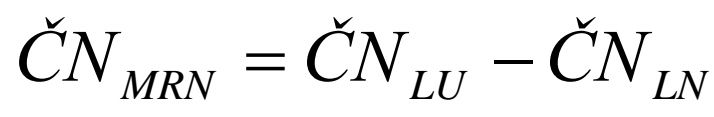


kde:

$\check{C} N_{M R N}$ čisté náklady kalkulované metodou rentability nákladi̊

$\check{C} N_{L U}$ čisté náklady operátora v připadě poskytování UPS $v$ liberalizovaném prostředi

$\check{C} N_{L N}$ čisté náklady operátora v př́padě neposkytování UPS v liberalizovaném prostředí

Metoda bývá v odborných kruzích kritizována zejména pro složitost její praktické implementace.

\section{Analýza způsobu výpočtu nákladů ve vybraných evropských zemích}

Ačkoli se v ČR zatím na stanovení vhodné metody kalkulace čistých nákladů UPS a následně na samotný výpočet čeká, některé evropské země již tyto náklady vypočítaly. Každá z těchto zemí přistupovala k výpočtu jiným způsobem a náklady zde byly zjišt’ovány $\mathrm{k}$ různým účelům.

Informace o použitých metodách, způsobu, postupu, účelu a výsledku kalkulace nákladů UPS v těchto evropských státech jsou zobrazeny v tabulce č. 1 .

tabulka č. 1 - Způsoby stanovení nákladů závazku univerzální poštovní služby ve vybraných evropských zemích

\begin{tabular}{|c|c|c|c|c|c|c|c|c|c|}
\hline \multirow{2}{*}{\multicolumn{2}{|c|}{\begin{tabular}{|l} 
země \\
model vypracoval
\end{tabular}}} & Belgie & \multicolumn{2}{|c|}{ Dánsko } & \multirow{2}{*}{$\begin{array}{c}\text { Francie } \\
\text { NPO }\end{array}$} & \multirow{2}{*}{$\begin{array}{c}\text { Norsko } \\
\text { NPO }\end{array}$} & \multirow{2}{*}{$\begin{array}{c}\text { Švýcarsko } \\
\text { NPO }\end{array}$} & \multicolumn{2}{|c|}{ Spojené království } \\
\hline & & NRA & $\begin{array}{c}\text { Dánský úrad } \\
\text { pro hosp. } \\
\text { soutěžž }\end{array}$ & $\begin{array}{l}\text { Copenhagen } \\
\text { Economics } \\
\text { (pro obch. komoru) }\end{array}$ & & & & NRA & $\begin{array}{c}\text { Frontier } \\
\text { Economics } \\
\text { (pro NRA) }\end{array}$ \\
\hline \multicolumn{2}{|l|}{ účel } & $\begin{array}{c}\text { zákonem } \\
\text { daný } \\
\text { požadavek }\end{array}$ & informativní & informativní & $\begin{array}{l}\text { požadavek } \\
\text { NRA }\end{array}$ & $\begin{array}{l}\text { oddělení } \\
\text { nákladũ od } \\
\text { podpory }\end{array}$ & $\begin{array}{c}\text { zákonem } \\
\text { daný } \\
\text { požadavek }\end{array}$ & informativní & informativní \\
\hline \multicolumn{2}{|l|}{ zaměření } & $\begin{array}{l}\text { produktové } \\
\text { účty }\end{array}$ & $\begin{array}{c}\text { produktové } \\
\text { úćty }\end{array}$ & $\begin{array}{l}\text { součásti } \\
\text { univerzální } \\
\text { služby }\end{array}$ & $\begin{array}{l}\text { součásti } \\
\text { univerzální } \\
\text { služby }\end{array}$ & $\begin{array}{l}\text { součásti } \\
\text { univerzální } \\
\text { služby }\end{array}$ & $\begin{array}{c}\text { produktové } \\
\text { účty }\end{array}$ & $\begin{array}{l}\text { produktové } \\
\text { účty }\end{array}$ & $\begin{array}{l}\text { součásti } \\
\text { univerzální } \\
\text { služby }\end{array}$ \\
\hline \multicolumn{2}{|c|}{ referenční scénár̆ } & ne & ne & ano & ano & ano & $\begin{array}{c}\text { částečně } \\
\text { (posstonni ưrady) }\end{array}$ & ne & ne \\
\hline \multicolumn{2}{|l|}{ metoda } & FDC & neznámá & MRN & MVN & MRN & $\begin{array}{c}\text { MVN } \\
\text { (poštonni úrady) }\end{array}$ & MVN & MRN \\
\hline \multicolumn{2}{|c|}{ kalkulováno v roce } & $?$ & 2005 & 2005 & $?$ & 2006 & 2007 & 1999/2000 & $2006 / 07$ \\
\hline \multirow{3}{*}{$\begin{array}{l}\text { výsledek } \\
\text { kalkulace }\end{array}$} & $\begin{array}{l}\text { částka v národní } \\
\text { měně (v milionech) }\end{array}$ & nepublikováno & 700 (DKK) & 150 (DKK) & nepublikováno & 253 (NOK) & 500 (CHF) & 91 (GBP) & 271 (GBP) \\
\hline & $\begin{array}{l}\text { částka v US\$ } \\
\text { (v milionech) }\end{array}$ & nepublikováno & 149 & 32 & nepublikováno & 50 & 50 & 181 & 542 \\
\hline & $\begin{array}{l}\text { z operativních } \\
\text { nákladů NPO (v \%) }\end{array}$ & nepublikováno & 7 & 1,5 & nepublikováno & 2,3 & 7,8 & 1,5 & 4 \\
\hline
\end{tabular}

Zdroj: DIEKE, A; NIEDERPRUEM, A. Efforts to Calculate the Cost of the USO and the Value of the Postal Monopoly in the US and Abroad. George Mason University [online]. 2008 [cit. 2009-08-10]. Dostupný z WWW: <http://www.prc.gov/PRC-DOCS/library/USO\%20Appendices/Appendix\%20F\%20Section\%201.pdf> 
U některých kalkulací nákladů provedených v evropských zemích uvedených v tabulce č. 1 bohužel nejsou zahrnuty tzv. benefity, které po zapracování do výpočtu mohou výsledek ještě značně ovlivnit. Z některých zdrojů vyplývá, že po zapracování těchto benefitů (např. v Dánsku v roce 2008 a ve Spojeném království v roce 2007) vyšel závazek UPS nulový.

V Belgii je požadavek zjištění nákladů UPS vznesen zákonem na NRA, jímž je BIPT (Belgian Institute for Postal services and Telecommunications). BIPT tyto náklady kalkuluje pravidelně metodou FDC. To je ale bohužel jen účetní metoda k prŕpravě oddělených regulačních účtů a nebere v potaz další př́slušné proměnné, $s$ kterými je potřeba při výpočtu čistých nákladů UPS počítat. Náklady na univerzální službu ${ }^{3}$ jsou vypočteny jako rozdíl mezi výdaji na UPS a ziskem ze služeb vyhrazených NPO. Výpočet je proveden na základě údajů z produktových účtů NPO. Referenční scénář v Belgii není stanoven a bohužel není k dnešnímu datu publikován ani výsledek výpočtů.

V Dánsku byly čisté náklady na UPS zjišt'ovány dvěma subjekty, a to Dánským úřadem pro hospodářskou soutěž $(\mathrm{DCA})^{4}$ a Kodaňskou ekonomikou pro obchodní komoru $(\mathrm{CE})^{5}$. Prvně jmenovaný subjekt kalkuloval na základě regulačních účtů NPO a bez stanoveného referenčního scénáře. Náklady počítal jako rozdíl výdajů na UPS a zisk z deseti produktových skupin (pět produktových skupin krát dva druhy doručovacích oblastí: venkovské a městské). DCA vyšly náklady na univerzální službu mnohem vyšší (7 \% z operativních nákladů poskytovatele UPS) než CE $(1,5 \%$ z operativních nákladů poskytovatele UPS), která kalkulovala na základě referenčního scénáře z analýzy segmentů univerzální služby. Kalkulace CE je provedena podrobněji a bere ohled i na ostatní specifika zajištění UPS.

Ve Francii kalkuloval čisté náklady př́mo poskytovatel UPS (La Poste). Výsledná částka bohužel nebyla publikována.

V Norsku byla UPS až do roku 2005 podporována ze státního rozpočtu. V roce 2006 vypočítal NPO náklady na UPS, aby mohl informovat stát o potřebě krytí závazku ze zisku z monopolních služeb, ze státní podpory nebo z obou zdrojů současně. Výsledek výpočtu vyšel na sumu ve výši 2,3 \% z operativních nákladů NPO.

Ve Švýcarsku kalkuloval NPO závazek UPS v roce 2007. Výpočet nákladů byl proveden jen pro omezenou oblast UPS zaměřenou na počet poštovních provozoven. Jednalo se hlavně o př́padný přesun poštovních úřadů do maloobchodních řetězců či naopak. Kalkulace nákladů vyšla na 7 \% z operativních nákladů NPO.

Ve Spojeném království byly čisté náklady na závazek UPS kalkulovány dvakrát. Nejdříve to bylo již mezi roky 1999 - 2000, kdy NRA (Postcomm) vypočítala závazek UPS na částku, která se rovnala $1,5 \%$ z operativních nákladů NPO. K výpočtu byly ale využity pouze produktové účty. O sedm let později Postcomm pověřil Frontier Economics, aby provedl komplexnější výpočet nákladů závazku univerzální poštovní služby. Frontier Economics použil model, který bral v potaz i ostatní proměnné spojené s poskytováním UPS. Výsledek pak byl o něco vyšší, než u starší studie NRA. Frontier Economics vyšla finanční částka závazku UPS ve výši 4 \% z operativních nákladů NPO.

\footnotetext{
${ }^{3}$ v belgické legislativě figuruje výraz „,nespravedlivá zátěž“ (unfair burden)

${ }^{4}$ angl. Danish Competition Authority

${ }^{5}$ angl. Copenhagen Economics
} 


\section{Závěr}

Vypočítat skutečné náklady závazku UPS je úkolem poskytovatele UPS a NRA, která by měla metodu i výpočet ověřit. Stávající český poskytovatel univerzální poštovní služby v současné době pracuje na strategii, jak bude postupovat, až se poštovní trh ČR plně otevře konkurenci, tj. zpracovávání referenčního scénáře. V této době lze pouze odhadovat výsledek v budoucnu provedeného výpočtu, nicméně po nutné restrukturalizaci stávajícího poskytovatele UPS a po modifikaci rozsahu a struktury závazku univerzální poštovní služby (v souladu s významem a pozicí poštovních služeb v moderní komunikační společnosti) lze prredpokládat dosažení podobných výsledků jako u ostatních evropských států.

\section{Seznam literatury}

[1] Funding universal service obligations in the postal sector. Oxera [online]. 2007 [cit. 2010-02-03]. Dostupný z WWW: <http://www.oxera.com/cmsDocuments/Funding\% 20universal\%20services\%20obligations\%20in\%20the\%20postal\%20sector.pdf $>$.

[2] LIJN, N. et al. Main developments in the European postal sector (2006 - 2008) - Final report. Ecorys [online]. Rotterdam, 2008 [cit. 2010-02-03]. Dostupný z WWW: <http://ec.europa.eu/internal_market/post/doc/studies/2008-ecorys-final_en.pdf>

[3] Směrnice 2008/6/EC Evropského parlamentu a Rady ze dne 20. února 2008, kterou se měnila směrnice 97/67/EC s ohledem na úplné dotvoření vnitřního trhu poštovních služeb Společenství

[4] Universal Service and its Financing. CERP [online]. 2009 [cit. 2010-02-03]. Dostupný z WWW:<http://www.cept-cerp.org/cerp/pdf\%5CUniversal\%20Service\%20and\%20 its\%20 Financing.pdf $>$.

[5] DIEKE, A; NIEDERPRUEM, A. Efforts to Calculate the Cost of the USO and the Value of the Postal Monopoly in the US and Abroad. George Mason University [online]. 2008 [cit. 2010-02-03]. Dostupný z WWW: <http://www.prc.gov/PRC-DOCS/library/ USO\%20Appendices/Appendix\%20F\%20Section\%201.pdf>

[6] EU Postal Legislation [online]. [cit. 2010-02-03]. Dostupné z <http://ec.europa.eu/ internal_market/post/legislation_en.htm>.

[7] ROTH, J. Podmínky zajištěni univerzální poštovní služby v př́padě plné liberalizace poštovního trhu ČR. Sborník příspěvků mezinárodní vědecké konference POSTPOINT 2009 “Globalization - a chance for postservices”. Žilina, 2009, s. 214-219. ISBN 978-80554-0085-3.

[8] PANZAR, J.C. A Methodology for Measuring the Costs of Universal Service Obligations, Information Economics and Policy 12, 2000, p. 211-220. ISSN 0167-6245.

[9] CREMER, H.; GRIMAUD, A.; LAFFONT, J. J. The cost of Universal Service in the Postal Sector. In CREW, M.; KLEINDORFER, P. Current Directions in Postal Reform. Boston: Kluwer Academic Publishers, 2000, p. 47-68. ISBN 978-0-7923-7807-5.

[10]ŠVADLENKA, L., ROTH, J. Problematika univerzální poštovní služby. Elektronický časopis Katedry spojov Žilinské univerzity: Pošta, telekomunikácie a elektronický obchod. 2008, s. 59 - 64. Dostupný z WWW: <http://ks.utc.sk/casopis/pdf/II2008/ svadlenka_roth.pdf $>$. ISSN 1336-8281. 
[11]ČOREJOVÁ, T., MADLEŇÁKOVÁ, L. K niektorým otázkam vývoja na poštových trhoch. In: Sbornik př́spěvkư z mezinárodní vědecké konference "Podniky v podmínkách procesu globalizace a integrace", 2004. s. 19-23.

[12]MADLEŇÁK, R., MADLEŇÁKOVÁ, L. The postal market analysis in Europe, In: Studies of Faculty of operation and economics of transport and communications of University of Žilina. s. 117-122.

[13]MOKOŠOVÁ a kol. Vybrané kapitoly z manažmentu v pošte a telekomunikáciach, Žilina 2003, EDIS, ISBN 80-7100-935-0.

[14]ROSTÁŠOVÁ, M., BÁŤKA, M. Poštová výhrada a liberalizácia na európskom poštovom trhu. Elektronický časopis Katedry spojov Žilinské univerzity: Pošta, telekomunikácie a elektronický obchod. 2008, s. 59 - 64. Dostupný z WWW: $<$ http://ks.utc.sk/casopis/pdf/II2008/ svadlenka_roth.pdf>. ISSN 1336-8281. 